\title{
KAWASAN WISATA SUNGAI CARANG KOTA TANJUNGPINANG DENGAN PENDEKATAN ARSITEKTUR METAFORA
}

\section{TOURISM DESTINATION “SUNGAI CARANG” AT TANJUNG PINANG BY USING METAPHORE ARCHITECTURE CONCEPT}

\author{
Wahyu Setiaji ${ }^{1}$ dan Supriyanto $^{2}$ \\ ${ }^{12}$ Teknik Arsitektur Universitas Riau Kepulauan \\ wahyu_arch@yahoo.com; priealmatra@gmail.com
}

\begin{abstract}
Abstrak
Semakin berkembangnya dunia kesenian di Kota Tanjungpinang bahkan di Provinsi Kepulauan Riau dan belum adanya wadah yang secara khusus mampu menampung kegiatan kesenian dan tempat terselenggaranya event Festival Bahari Kepri. Dalam menanggapi hal tersebut tercipta gagasan untuk merencanakan Kawasan Wisata Sungai Carang Kota Tanjungpinang yang dilengkapi dengan fasilitas pendukung yang lengkap dan relevan untuk mengakomodasi segala kegiatan yang berhubungan dengan kegiatan kesenian. Arsitektur metafora diaplikasikan sebagai konsep pembentukan massa bangunan untuk memenuhi kebutuhan kegiatan kesenian.
\end{abstract}

Kata kunci : Kawasan Wisata Sungai Carang Kota Tanjungpinang

\begin{abstract}
The growing art world in Tanjungpinang even in Riau Islands Province and the absence of a container that is specifically able to accommodate the arts activities and place the implementation of the Riau Islands Maritime Festival event. In response, the idea was created to plan the Carang River Tourism Area of Tanjungpinang City equipped with complete supporting facilities and relevant to accommodate all activities related to the arts activities. Metaphorical architecture is applied as a concept of building mass to meet the needs of artistic activities.
\end{abstract}

Keywords: Tourism Area Carang Rivers Tanjungpinang, Architecture Metaphor

\section{PENDAHULUAN}

Kota Tanjungpinang merupakan salah satu pusat kebudayaan melayu, karena hingga saat ini melayu masih kental dalam kehidupan sehari-hari masyarakatnya. Seperti Gurindam 12 yang diciptakan oleh Raja Ali Haji mengangakat citra negeri ini bahkan tersohor keseluruh negeri. Begitu juga dengan julukan "kota gurindam negeri pantun" yang hingga saat ini masyarakatnya tidak pernah lupa akan sejarah dan budaya Melayu.

Setiap tahunnya warga Provinsi Kepri patut berbangga dan bergembira karena terpilihnya provinsi Kepri menjadi salah satu provinsi dari beberapa provinsi yang ambil bagian dalam rangkaian event Akbar Indonesia, Sail 
Karimata di Tahun ini. Sail Karimata adalah nama pengganti dari Sail Indonesia 2016, yang merupakan Reli para pelayar dunia untuk mengarungi perairan di Indonesia, yang mana program ini adalah salah satu program andalan promosi pariwisata Indonesia. Pada tahun 2016, terdapat beberapa daerah di indonesia yang di kunjungi oleh para pelayar dari berbagai negara di dunia tersebut, empat provinsi terpilih untuk ambil bagian menyambut para pelayar-pelayar dunia tersebut diantaranya Provinsi Kalimantan Barat, Jambi , Provinsi Bangka Belitung, dan Provinsi Kepulauan Riau (KEPRI). Sailkarimata 2016 dibuka dengan seminar kemaritiman yang dilaksanakan di provinsi jambi , kemudian Festival Sail Karimata di Kayong Utara Kalimantan Barat, Festival Bahari Provinsi bangka belitung, dan Festival Bahari Kepri sebagai puncak dari rangkaian tersebut. Kesempatan emas tersebut tidak disia-siakan oleh provinsi Kepri, peluang memperkenalkan potensi daerah, terutama wisata dan budaya yang dimiliki provinsi Kepri kepada dunia sangat besar dengan ikut sertanya dalam acara rangkaian sail karimata tersebut, tidak tanggung-tanggung, pesta rakyat yang bertajuk FESTIVAL BAHARI KEPRI yang digelar pada bulan oktober tahun 2016. Lebih dari 30 kegiatan akan dilaksanakan di provinsi Kepri menjadi bagian dari rangkaian sail karimata tersebut. Tiga daerah di Provinsi Kepri menjadi pemusatan kegiatan FESTIVAL BAHARI tersebut, diantaranya Kota Batam, Kabupaten Bintan dan Kota Tanjungpinang. Namun hampir 75\% kegiatan Festival akan di gelar di Ibukota Provinsi Kepri, yaitu kota Tanjungpinang. Ada banyak pertunjukan kebudayaan lokal masyarakat Kepri, kuliner dan pertujukan seni Khas Melayu. selain pertunjukan yang telah di sebutkan sebelumnya , akan ada pula banyak perlombaan permainan tradisional yang digelar di kota Tanjungpinang, diantaranya perlobaan perahu naga, Lomba perahu Jong, Lomba Renang Tradisional, Lomba sampan layar, lomba sampan dayung parade kapal hias yang akan memecahkan rekor MURI, parade mobil hias dan masih banyak lagi kegiatan lainnya. Obyek wisata adalah salah satu komponen yang penting dalam industri pariwisata dan salah satu alasan pengunjung melakukan perjalanan (something to see). Di luar negri obyek wisata disebut tourist atraction (atraksi wisata), sedangkan di Indonesia lebih dikenal dengan objek wisata. Mengenai pengertian objek wisata. 
Permasalahan yang dihadapi adalah bagaimana merencanakan wadah kegiatan serta menampaung para komunitas kesenian dan juga pelajar berimajinasi, berekspresi, berkreasi, dan kreatif menciptakan karya kesenian dengan pendekatan arsitektur metafora sebagai ciri khas pada massa bangunan.

Tujuan dari perancangan kawasan ini diharapkan mampu mewadahi semua kegiatan kesenian dengan pendekatan arsitektur metafora. Perancangan ini diharapkan mampu menerepkan prinsip pendekatan arsitektur metafora kedalam kawasan wisata sehingga penyampaian pengumpamaan akan dimengerti oleh pengunjung maupun masyarakat.

\section{METODOLOGI}

\section{Analisa Perancangan}

Analisa dalam peranccangan berfungsi untuk mengidentifikasi masalah maupun potensi yangvada dalam perancangan. Analisa dilakukan terdiri dari analisa fisik dan non fisik. Analisa fisik didasarkan pada keadaan lingkungan tapak, sedangkan non fisik mengidentifikasi pengunjung dan aktivitas kegiatan dalam bangunan. Sebagai pembetukan massa bangunan juga membutuhkan analisa arsitektural, struktural maupun mekanikal elektrikal.

\section{PEMBAHASAN}

\section{Konsep Perancangan}

Dari referensi, analisa data - data, survey lapangan serta studi tata guna lahan maka diperoleh :

Luas lahan : $18.000 \mathrm{~m} 2$

$\operatorname{KDB}(50 \%): 10.981 .6 \mathrm{~m} 2$

$$
\begin{array}{ll}
\operatorname{KLB}(4) & : 0.6 \\
\text { GSB } & : 50 \mathrm{~m} \text { (depan) } \\
& 15 \mathrm{~m} \text { (samping) }
\end{array}
$$

Berikut ini merupakan kebutuhan ruang galeri fotografi;

a. Program Ruang 
Tabel 1. Program Ruang

\begin{tabular}{|c|c|c|c|c|}
\hline No. & $\begin{array}{l}\text { Macam } \\
\text { Kegiatan }\end{array}$ & Nama Ruang & Standar & Luas \\
\hline \multirow[t]{12}{*}{1} & Gedung & Hall & $0.8 \mathrm{~m}^{2} /$ orang & 160 \\
\hline & Kesenian & Informasi & $6 \mathrm{~m}^{2} /$ orang & 12 \\
\hline & & Ruang Pamer & $3 \mathrm{~m}^{2} /$ unit & 60 \\
\hline & & Ruang Seminar & $0.8 \mathrm{~m}^{2} /$ orang & 40 \\
\hline & & R. Kuratorial & $6 \mathrm{~m}^{2} /$ orang & 12 \\
\hline & & R. Nonton Vip & $0.8 \mathrm{~m}^{2} /$ orang & 40 \\
\hline & & Lavatory wanita & $0,9 \mathrm{~m} 2 /$ wastafel & 2.7 \\
\hline & & & $2 \mathrm{~m} 2 /$ toilet & 10 \\
\hline & & Lavatory Pria & $0,8 \mathrm{~m} 2 /$ urinoir & 2.4 \\
\hline & & & $0,9 \mathrm{~m} 2 /$ wastafel & 1.8 \\
\hline & & & $2 \mathrm{~m} 2 /$ toilet & 6 \\
\hline & & & & 346.9 \\
\hline \multirow[t]{7}{*}{2} & Lapangan & Panggung & $0.8 \mathrm{~m}^{2} /$ orang & 60 \\
\hline & Terbuka & Hall & $\begin{array}{l}0.8 \mathrm{~m}^{2} / \mathrm{seat}+16 \mathrm{~m}^{2} \\
\text { lecturer }\end{array}$ & 256 \\
\hline & & R. Kontrol & $12 \mathrm{~m}^{2} /$ ruang & 12 \\
\hline & & $\begin{array}{l}\text { R. Persiapan / Back } \\
\text { Stage }\end{array}$ & $20 \mathrm{~m}^{2} /$ ruang & 60 \\
\hline & & R. Penyimpanan & $25 \mathrm{~m}^{2} /$ ruang & 25 \\
\hline & & Lavatory & $6 \mathrm{~m}^{2} /$ unit & 12 \\
\hline & & & & 400 \\
\hline \multirow[t]{5}{*}{3} & Dermaga & Ponton & $50 \mathrm{~m}^{2} /$ unit & 100 \\
\hline & & Selasar & $12 \mathrm{~m}^{2} /$ unit & 24 \\
\hline & & R.Jaga & $12 \mathrm{~m}^{2} /$ unit & 24 \\
\hline & & R.Tunggu & $18 \mathrm{~m}^{2} /$ unit & 36 \\
\hline & & & & 184 \\
\hline \multirow[t]{12}{*}{4} & Cafetaria & Hall & $0.8 \mathrm{~m}^{2} /$ orang & 40 \\
\hline & & Ruang Makan & $5,32 / 4$ orang & 265 \\
\hline & & Dapur & $20 \mathrm{~m}^{2} /$ orang & 20 \\
\hline & & Kasir & $4 \mathrm{~m}^{2} /$ ruang & 4 \\
\hline & & Lavatory wanita & $0,9 \mathrm{~m} 2 /$ wastafel & 1.8 \\
\hline & & & $2 \mathrm{~m} 2 /$ toilet & 4 \\
\hline & & Lavatory pria & $0,8 \mathrm{~m} 2 /$ urinoir & 2.4 \\
\hline & & & $0,9 \mathrm{~m} 2 /$ wastafel & 1.8 \\
\hline & & & $2 \mathrm{~m} 2$ / toilet & 4 \\
\hline & & R. Penyimpanan & $12 \mathrm{~m}^{2} /$ unit & 12 \\
\hline & & R. Pegawai & $12 \mathrm{~m}^{2} /$ unit & 12 \\
\hline & & & & 367 \\
\hline \multirow[t]{3}{*}{5} & Kios & Kios & $9 \mathrm{~m}^{2} /$ unit & 90 \\
\hline & Penjualan & Toilet & $2 \mathrm{~m} 2 /$ toilet & 20 \\
\hline & & & & 110 \\
\hline 6 & Mushola & R.Sholat & $36 \mathrm{~m}^{2} /$ unit & 36 \\
\hline
\end{tabular}




\begin{tabular}{|c|c|c|c|c|}
\hline & & $\begin{array}{l}\text { Tempat Wudhu Pria } \\
\text { Tempat Wudhu } \\
\text { Wanita }\end{array}$ & $\begin{array}{l}6 \mathrm{~m}^{2} / \text { unit } \\
6 \mathrm{~m}^{2} / \text { unit }\end{array}$ & $\begin{array}{l}6 \\
6\end{array}$ \\
\hline & & & & 48 \\
\hline \multirow[t]{6}{*}{7} & Toilet Umum & Lavatory wanita & $0,9 \mathrm{~m} 2 /$ wastafel & 3.6 \\
\hline & & & $2 \mathrm{~m} 2 /$ toilet & 12 \\
\hline & & Lavatory Pria & $0,8 \mathrm{~m} 2 /$ urinoir & 3.6 \\
\hline & & & $0,9 \mathrm{~m} 2$ / wastafel & 3.6 \\
\hline & & & $2 \mathrm{~m} 2 /$ toilet & 8 \\
\hline & & & & 30.8 \\
\hline \multirow[t]{7}{*}{8} & Ruang & Sitting area & $2 \mathrm{~m}^{2} /$ unit & 40 \\
\hline & Terbuka & Plaza & $5 \mathrm{~m}^{2} /$ unit & 25 \\
\hline & Hijau & Gazebo & $5 \mathrm{~m}^{2} /$ unit & 25 \\
\hline & & Taman Bunga & $50 \mathrm{~m}^{2} /$ area & 250 \\
\hline & & Jogging track & $200 \mathrm{~m}^{2} /$ area & 600 \\
\hline & & Parkir sepeda & $20 \mathrm{~m}^{2} /$ unit & 20 \\
\hline & & & & 960 \\
\hline \multirow[t]{7}{*}{9} & Service & R. Genset & $12 \mathrm{~m}^{2} /$ unit & 12 \\
\hline & & R. Trafo PLN & $9 \mathrm{~m}^{2} /$ unit & 9 \\
\hline & & R. Security & $9 \mathrm{~m}^{2} /$ unit & 9 \\
\hline & & R. Perlengkapan & $12 \mathrm{~m}^{2} /$ unit & 12 \\
\hline & & R. Kontrol & $12 \mathrm{~m}^{2} /$ unit & 12 \\
\hline & & ATM Centre & $4 \mathrm{~m}^{2} /$ unit & 16 \\
\hline & & & & 70 \\
\hline
\end{tabular}

Sirkulasi

1510.1

Jumlah Total

4026.8

b. Kebutuhan Ruang Parkir

Tabel 2. Ruang Parkir Pengelola

\begin{tabular}{lll}
\hline Kebutuhan Parkir Pengelola & & Luas $\left(\mathbf{m}^{2}\right)$ \\
\hline Jenis & Kapasitas (unit) & \\
\hline Mobil & 6 & 108 \\
Motor & 20 & 40 \\
\hline Jumlah Luas Parkir Pengelola & & 148 \\
\hline
\end{tabular}


Tabel 3. Ruang Parkir Pengunjung

\begin{tabular}{lll}
\hline Kebutuhan Parkir Pengunjung & & Luas $\left(\mathbf{m}^{\mathbf{2}}\right)$ \\
\hline Jenis & Kapasitas (unit) & \\
Mobil & 21 & 378 \\
Motor & 36 & 126 \\
Bus & 2 & 80 \\
Jumlah Luas Parkir Pengelola & & 584 \\
Luas Total & & 732 \\
Sirkulasi 100\% & & 732 \\
\hline Luas Total Parkir & $\mathbf{1 4 6 4}$ \\
\hline
\end{tabular}

Jadi total luas bangunan

$$
\begin{aligned}
& =4026.8+1464 \mathrm{~m} 2 \\
& =5490.8 \mathrm{~m} 2
\end{aligned}
$$

Konsep Pengolahan Site

Pengolahan site berdasarkan analisa terhadap lingkungan site sehingga mendapatkan respon sebagai bahan pengolahan site. Orientasi diarahkan ke sungai carang dengan pertimbangan mampu menarik pengunjung yang lewat disekitar site. Perletakan massa bangunan berada di tengah site dengan tujuan untuk menciptakan point of interest.

Bentuk Massa Bangunan

Bentuk massa bangunan yang dihasilkan dari respon terhadap analisa klimatologi dan juga analisa view terhadap site. Arsitektur metafora digunakan juga sebagai pembentukan massa bangunan utama dengan pengumpamaan bentuk kapal dan elemen-elemen kapal didalamnya. 
P ISSN 2614-5979

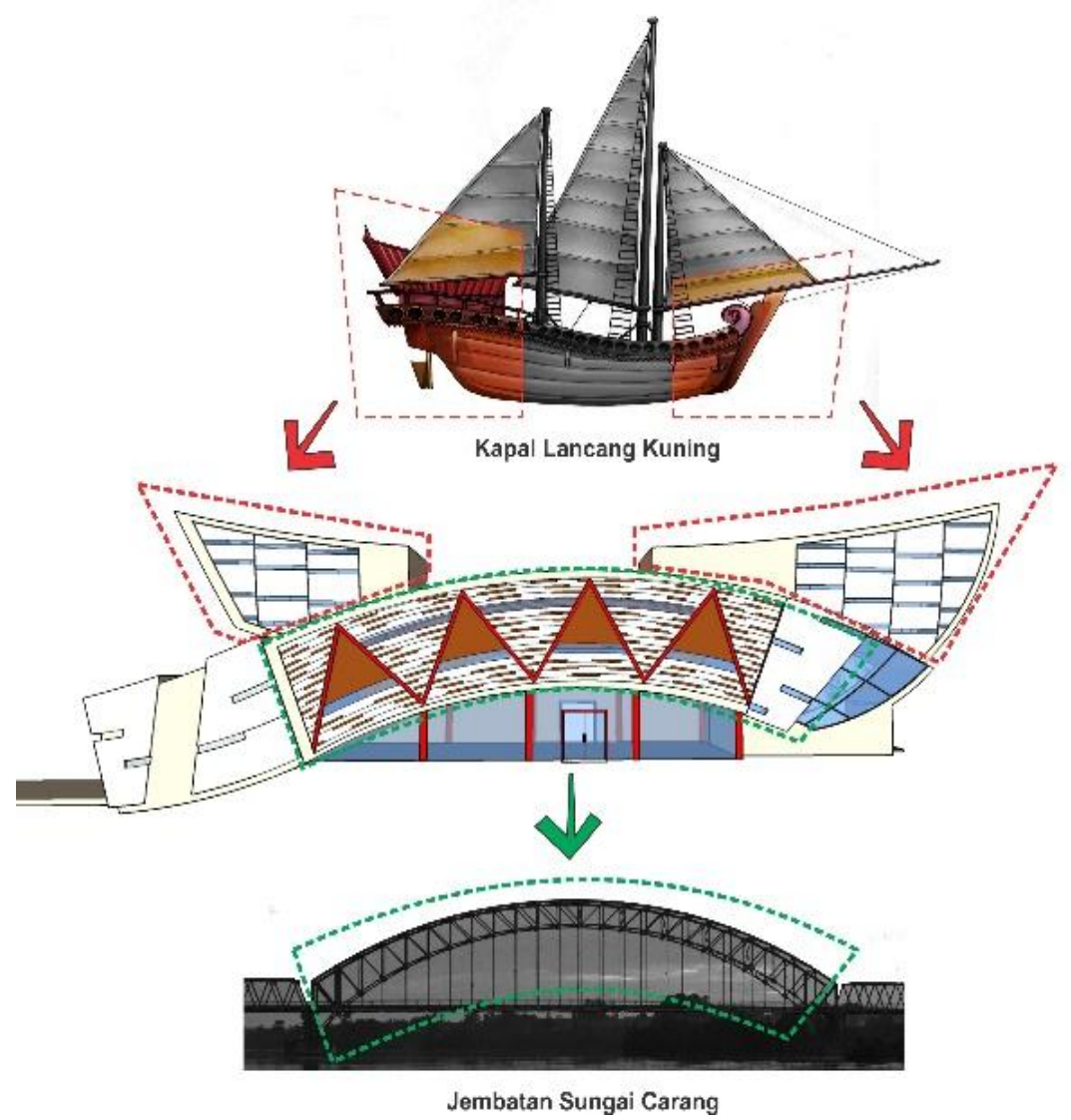

Konsep Struktur

Sistem struktur yang digunakan pada bangunan adalah sistem rangka yang terdiri dari balok dan kolom untuk menyalurkan beban ke dalam tanah melalui pondasi.

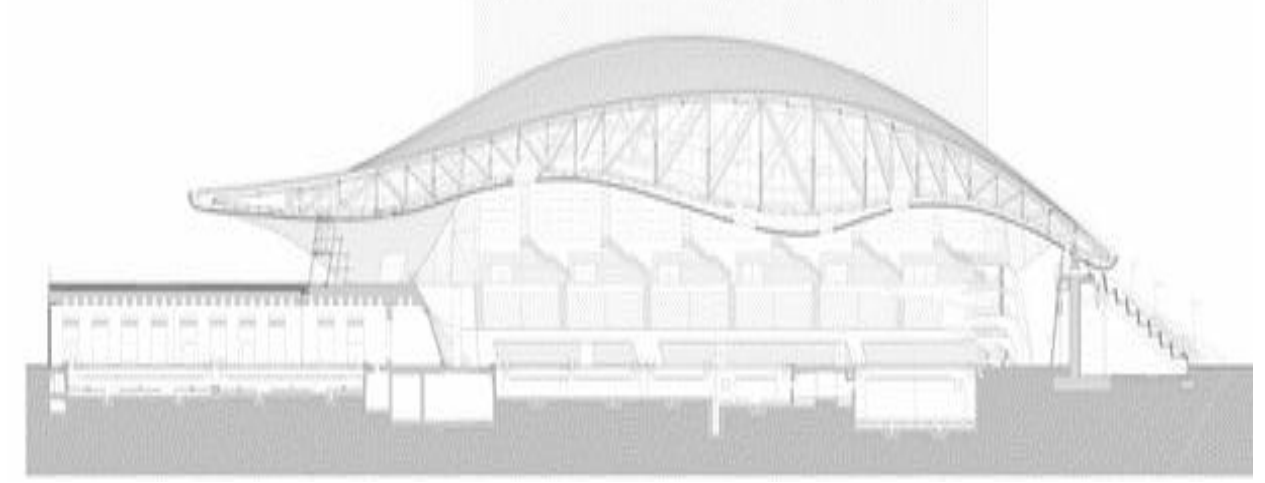

Konsep Utilitas 
a. Pencahayaan

Konsep pencahayaan dalam bangunan disesuaikan dengan fungsi ruang dalam bangunan. Pencahayaan buatan digunakan didalam ruang seminar dan ruang pamer. Sedangkan pencahayaan alami digunakan pada ruang pertunjukan dan hall.

b. Penghawaan

Untuk menunjang peralatan dan perlengkapan kesenian agar tidak lembab dan berjamur, penghawaan dalam bangunan terutama ruang pamer dan seminar diupayakan tetap dingin dan menghindari kelembaban. Maka konsep penghawaan menggunakan penghawaan alami (cross ventilation) dan penghawaan buatan.

\section{KESIMPULAN DAN SARAN}

\section{Kesimpulan}

Dari hasil analisa terhadap perancangan Kawasan Wisata Sei Carang Kota Tanjungpinang dengan Pendekatan Arsitektur Matefora yang sebelumnya telah dilaksanakan kajian terhadap studi literatur dan studi banding yang telah diterapkan kedalam hasil perancangan, dapat ditarik kesimpulan. Beberapa kesimpulan yang dapat diambil antara lain:

Perancangan Kawasan Wisata Sei Carang Kota Tanjungpinang yang memiliki tujuan utama sebagai wadah terselenggaranya event Festival Bahari yang diadakan setahun sekali dikota Tanjungpinang, yang dimana event ini bertaraf internasional. Perancangan Kawasan Wisata Sei Carang Kota Tanjungpinang berada pada site yang strategis dan diakomodasi dengan berbagai macam kendaraan, serta memiliki utilitas kota yang memadai seperti drainase, jaringan listrik, jaringan telepon. Lokasi tapak berada di Jalan Sei Carang, Kota Tanjungpinang.

Kawasan Wisata Sei Carang merupakan kawasan yang memiliki area hijau sekitar 30\% dari total luas site. Bentuk massa bangunan pada kawasan dihasilkan dari respon analisa matahari, angin, dan juga analisa view dari tapak maupun ke dalam tapak dengan penentuan tapak berada di tengah-tengah site, orientasi mengarah ke sungai carang. Dengan pendekatan arsitektur metafora pada massa 
bangunan gedung kesenian bisa menciptakan kesan yang atraktif, berekspresi, berimajinasi sesuai dengan kegiatan yang ada didalam Kawasan Wisata Sei Carang. Sistem pencahayaan dan penghawaan pada gedung kesenian umumnya menggunakan pencahayaan buatan dengan pertimbangan kelembapan udara di dalam hall, ruang seminar, dan ruang nonton, dll.

\section{Saran}

Penulis juga bermaksud memberikan saran yang berkaitan dengan perancangan Kawasan Wisata Sei Carang kepada pembaca yang akan merencanakan Kawasan Wisata Sei Carang dengan pendekatan arsitektur metafora :

Pemilihan lokasi tapak sebaiknya dilakukan dengan melakukan analisa terhadap lokasi tapak dengan beberapa kriteria sesuai dengan fungsi Kawasan Wisata Sei Carang. Sebagai tempat yang bersifat publik harus memperhatikan bentuk massa bangunan supaya bisa dipahami dan diterima oleh pengunjung.

Didalam ruang gedung kesenian pencahayaan harus diperhatiakan karena dari sistem pencahayaan dapat tercipta suasana yang dinginkan perancang. Suhu udara didalam bangunan sangat diperhatikan untuk menjaga kelembapan yang mengakibatkan jamur bahkan bisa merusak karya kesenian. Dalam pengelolaan bangunan tersebut harus memperhatikan kapasitas listrik sebagai sumber energi yang digunakan dalam bangunan.

\section{DAFTAR PUSTAKA}

Ching, D. K 2007. Architecture : From, Space And Order 3rd Edition. Newjersey : John Wiley \& Sons, Inc.

Neufert, Ernst. “Data Arsitek”Edisi Kedua, Jakarta. 1990. https://robbihafzan.wordpress.com/2016/10/03/festival-bahari-kepri016/menixnews.com/20-30-oktober-ini-ada-festival-bahari-kepri-di tanjungpinang- apa-sih-yang-bisa-dilihat-baca-ulasannya-ya/

http://putrizulvao.blogspot.co.id/2013/03/kebudayaan-kepulauan-riau.html http://www.riaudailyphoto.com/2011/11/ragam-motif-ukiran-dalamarsitektur.html

http://en.wikipedia.org/wiki/sungaicarang http://en.wikipedia.org/wiki/lancangkuning 
http://en.wikipedia.org/wiki/bpskotatanjungpinang

http://en.wikipedia.org/wiki/bpskepulauanriau

https://id.wikipedia.org/wiki/keseniankepulauanriau

FuturArc $2^{\text {nd }}$ quarter 2012 Vol.25

RTRW Kota Tanjungpinang 2011-2031

RTRK Kota Tanjungpinang 2011-2016

TanjungpinangDalamAngka 2014 


\section{SITEPLAN}
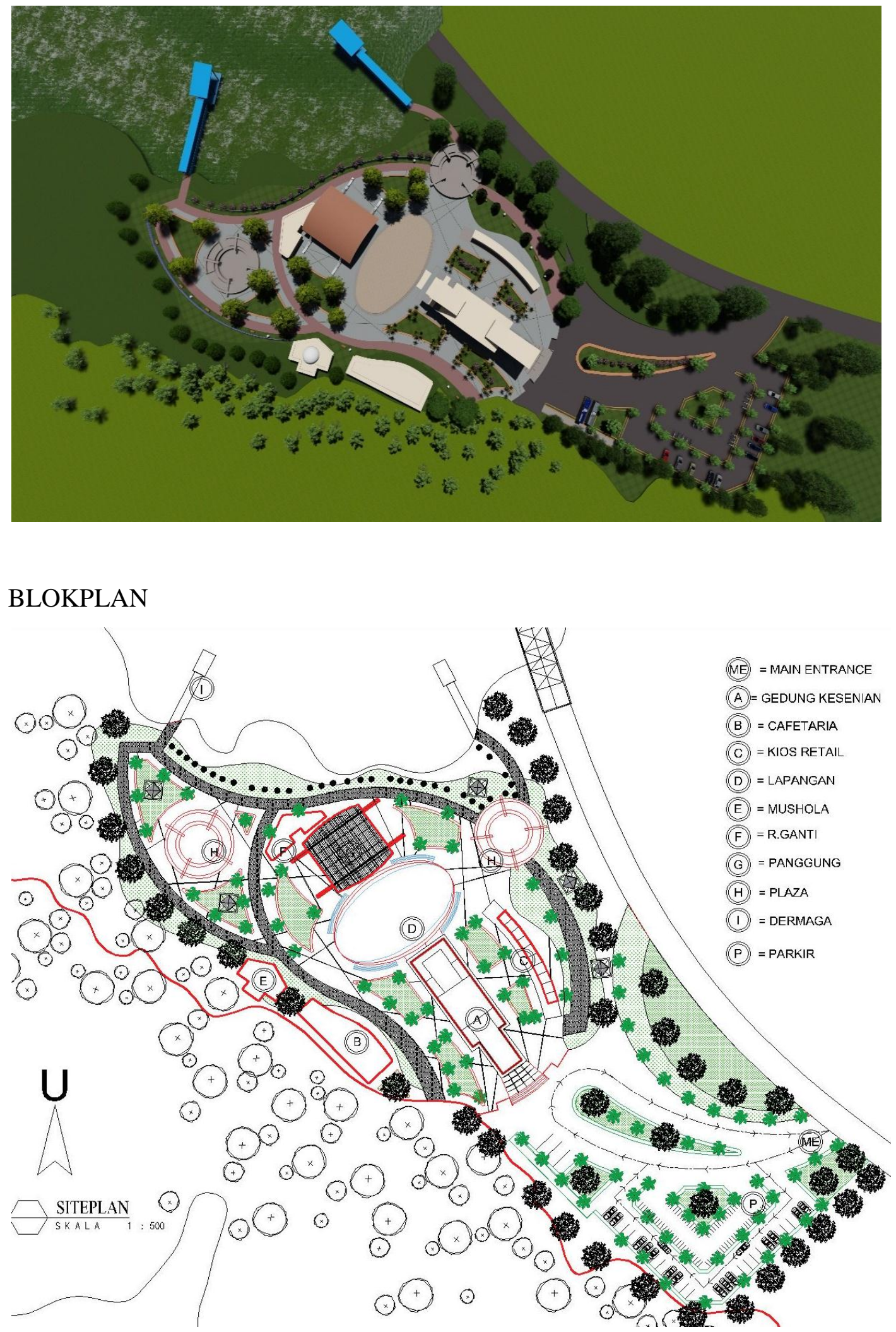

DENAH LANTAI 1 
Sigma Teknika, Vol.1, No.1 : 107-121

Februari 2018

E-ISSN 2599-0616

P ISSN 2614-5979

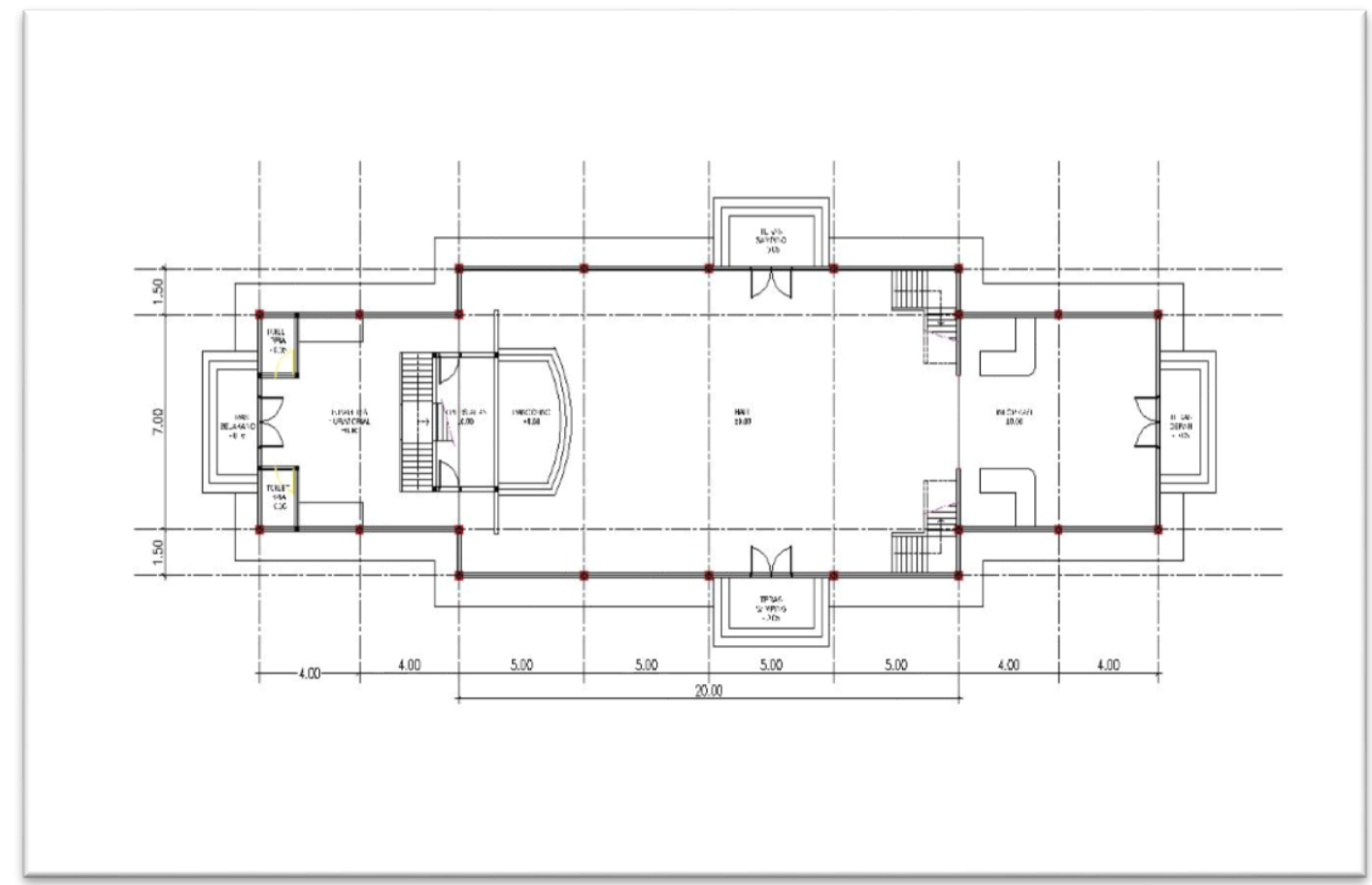

DENAH LANTAI 2

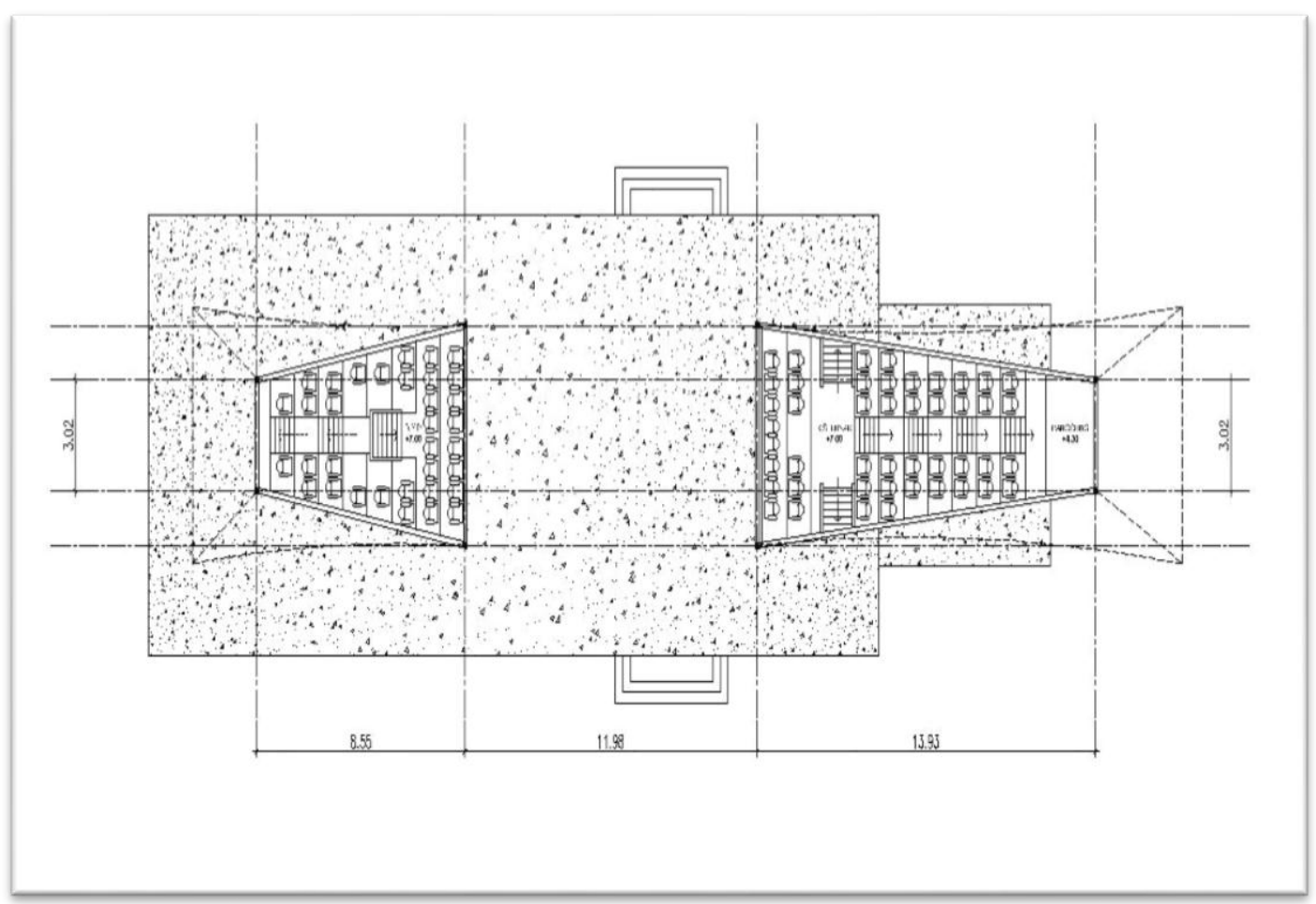

\section{PERSPEKTIF}


Sigma Teknika, Vol.1, No.1 : 107-121

Februari 2018

E-ISSN 2599-0616

P ISSN 2614-5979
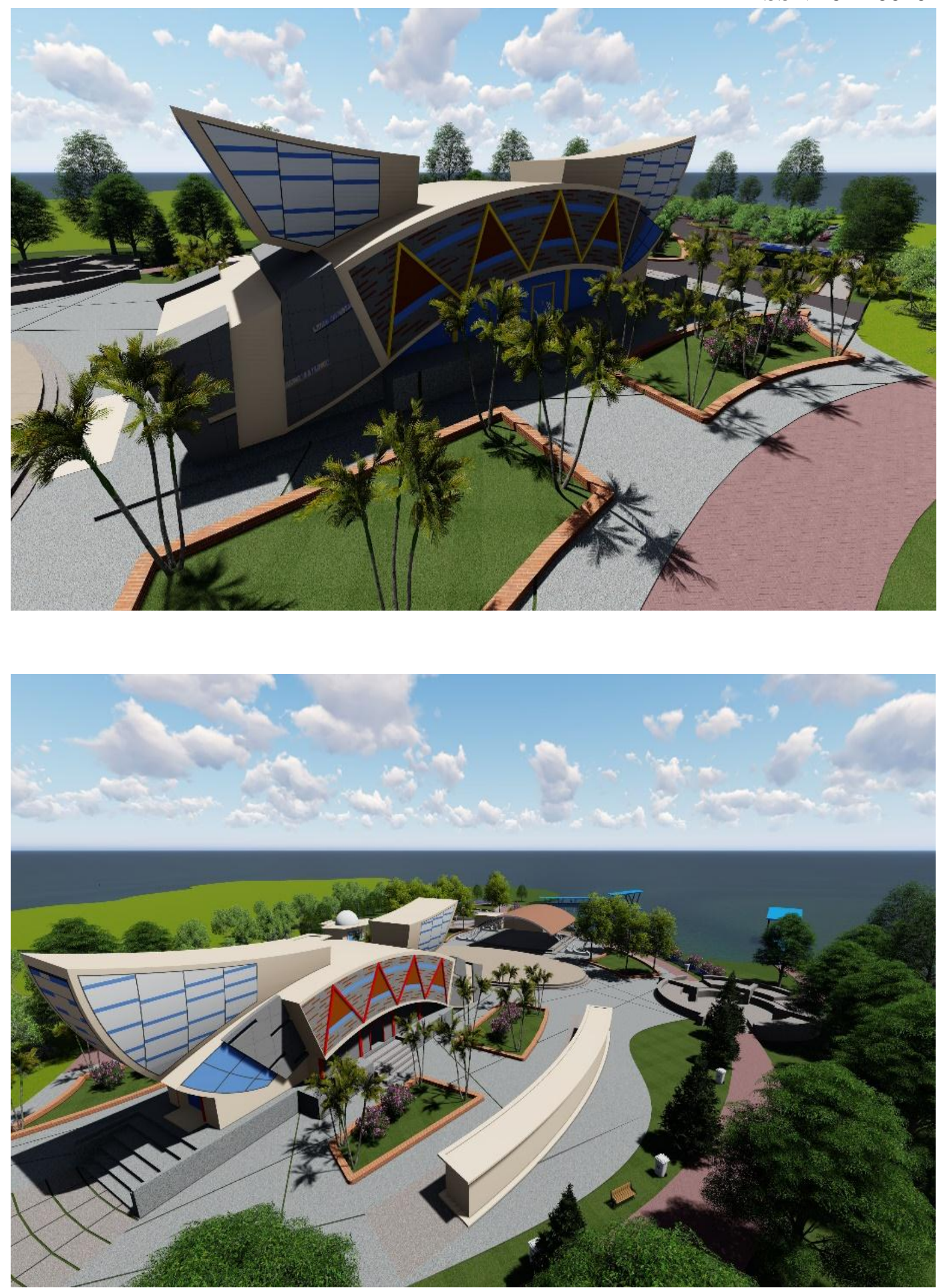
Sigma Teknika, Vol.1, No.1 : 107-121

Februari 2018

E-ISSN 2599-0616

P ISSN 2614-5979
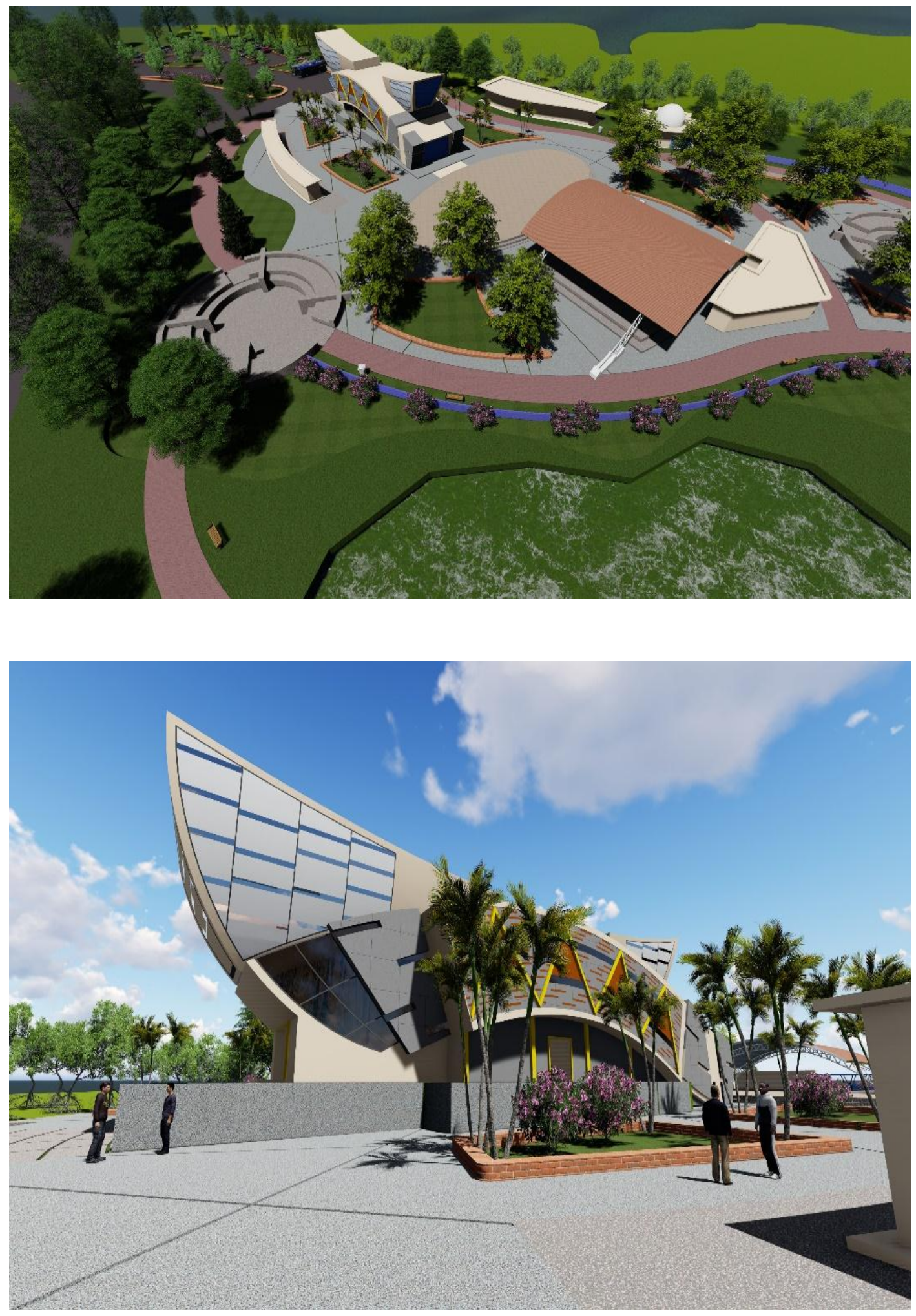
Sigma Teknika, Vol.1, No.1 : 107-121

Februari 2018

E-ISSN 2599-0616

P ISSN 2614-5979
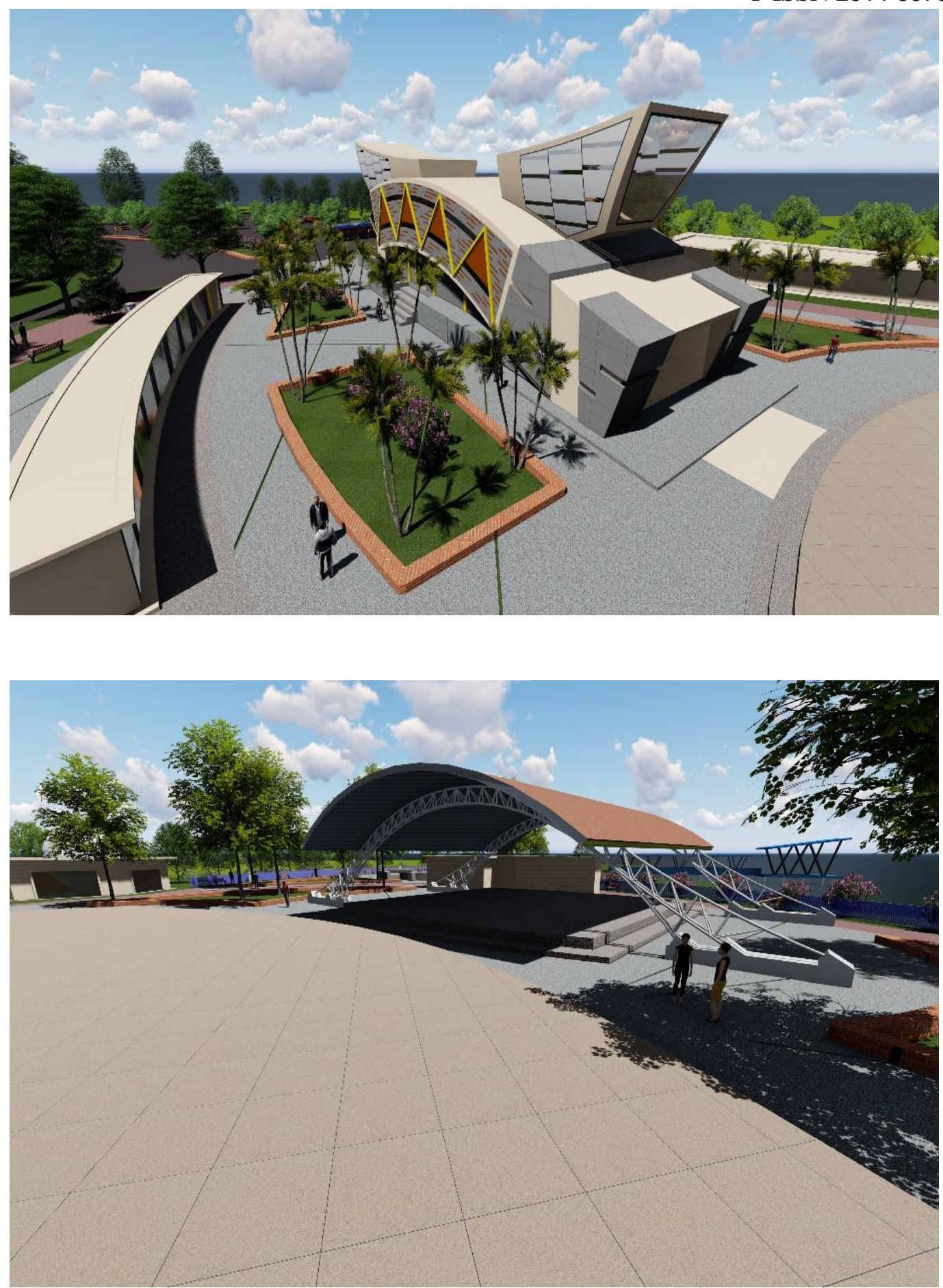